\title{
A green winner's curse? Investor behavior in the market for eco-certified office buildings
}

Article

Accepted Version

Creative Commons: Attribution-Noncommercial-No Derivative Works 4.0

Fuerst, F., Gabrieli, T. and McAllister, P. (2017) A green winner's curse? Investor behavior in the market for ecocertified office buildings. Economic Modelling, 61. pp. 137146. ISSN 0264-9993 doi:

https://doi.org/10.1016/j.econmod.2016.11.007 Available at https://centaur.reading.ac.uk/69598/

It is advisable to refer to the publisher's version if you intend to cite from the work. See Guidance on citing.

To link to this article DOI: http://dx.doi.org/10.1016/j.econmod.2016.11.007

Publisher: Elsevier

All outputs in CentAUR are protected by Intellectual Property Rights law, including copyright law. Copyright and IPR is retained by the creators or other copyright holders. Terms and conditions for use of this material are defined in the End User Agreement.

www.reading.ac.uk/centaur 
Central Archive at the University of Reading

Reading's research outputs online 


\title{
A Green Winner's Curse? Investor Behavior in the Market for Eco-Certified Office Buildings
}

\author{
FRANZ FUERST*, TOMMASO GABRIELI** AND PATRICK MCALLISTER***
}

\begin{abstract}
This paper contributes to the growing literature on the economics of green buildings: by merging auction theory and hedonic regression analysis we investigate the relationship between market concentration and price premiums in the American market for eco-certified real estate assets. Auction theory is used to model price formation where eco-investors may differ in their valuation of assets. Controlling for a large number of features, the empirical results provide evidence of a significant and positive relationship between investors' eco-certified market share and prices of eco-certified space. Contributing to the recent debate over the nature of the green premium, we find that eco-investors are creating clientele effects and that they may be subject to a green winner's curse.
\end{abstract}

Key-Words: Green Building, Eco-certification premium, Real Estate auctions, Winner's curse.

Acknowledgments: We thank the CoStar Group for their generous support in granting us access to the large dataset needed to perform this analysis. Franz Fuerst gratefully acknowledges the continuous support of the Cambridge University Land Society (CULS) in supporting his research. We are grateful to the editor of this journal and to two anonymous referees who provided substantial comments and guidance to improve the quality of this article. All errors remain our own.

*Department of Land Economy, University of Cambridge.

**Corresponding Author: Bartlett School of Planning, University College London, Central House, 14 Upper Woburn Place, WC1H 0NN, London, UK. Email: t.gabrieli@ucl.ac.uk

***Real Estate and Planning, Henley Business School, University of Reading.

\section{Research Highlights}


- A novel analysis on market concentration and price premiums for green buildings.

- We find evidence of a "green winner's curse".

- Investors with higher market share of eco-certified assets pay higher prices.

- The "green winner's curse" explains the widely observed price premium. 


\section{Introduction}

The increase in attention to "sustainable" or "green" building over the present decade has been remarkable. This reflects popular concern with environmental preservation, as well as changes in tastes among consumers and investors. In the real estate sector, a blend of mandatory government regulation and voluntary industry standards has emerged in response to pressure to reduce the negative environmental impact of the building stock. There has been growing interest among real estate investors, developers, occupiers, as well as regulators and policy makers, in the effects of environmental certification on the financial performance of real estate assets. This has motivated, within the growing body of research focused on sustainability issues, a novel research strand specifically focused on certification-related pricing issues.

In particular, a number of studies have found empirical evidence of financial benefits (see for example, Eichholtz, Kok, and Yonder (2012) on US, Devine and Kok (2015) on US and Canada, Deng and Wu (2013) on Singapore, Chegut, Eichholtz, and Kok (2014) on UK). Interestingly, the financial value of green buildings does not appear to be limited to operational costs: Eichholtz, Kok, and Quigley (2013) and Reichardt (2014) find a premium for the sustainability certification that goes beyond reduced energy and operating expenses. Having said that, because green building certification allows for flexibility and does not entail specific technological requirements and because each type of green building or energy efficiency label is unique, some authors have referred to green certification as a "noisy" signal of building quality (see Fuerst and McAllister 2011b and Kok, McGraw, and Quigley 2012).

To date, there has been virtually no theoretical research on the nature and causes of such certification premium. In this paper we take a natural first step to address this gap by focusing on the role that the price formation mechanism can play on investors' behavior and on the resulting certification premium. We draw upon standard auction theory to develop a model of optimal bidding behavior for real estate assets; the model generates 
theoretical estimates of the price premium associated with a given market share. Second, using a database of more than 2,700 commercial real estate transactions of Class A offices that took place between January 2007 and March 2012, we test the theoretical predictions of the model by employing hedonic regression analysis; in particular we examine whether eco-investors generally pay additional premiums for eco-certified assets.

Our paper contributes to three different strands of the literature. Firstly, the existing literature on real estate auctions is small, especially on the theoretical side (the usually cited models are those of Quan (1994), Adams et al. 1992, Mayer 1995); our paper contributes to this literature by developing a simple model that gives clean theoretical predictions on the relationship between investor's market share and paid price premium and that could be further applied to other auction-based markets. Secondly, the increasing attention to the environmental impact of commercial real estate has generated a developing body of empirical research that has focused on pricing and in particular on US commercial real estate assets; see, among others, Eichholtz, Kok and Quigley (2011, 2013), Wiley, Benefield and Johnson (2010), Fuerst and McAllister (2011a, 2011b) and Miller, Spivey and Florance (2008). Following those contributions, we empirically investigate the ecocertification premium using the large Co-Star database ${ }^{1}$, but our novel contribution is to account for the investor's market share as an explanatory variable of the observed price premium. By doing this, we find that investors with a higher market share of eco-certifies assets tend to pay higher prices, other things equal, therefore we find evidence of a green winner's curse". Thirdly, in the market segmentation literature, there is a longstanding body of work suggesting that the size and nature of the investor base affects security prices. Most notably, explanations of the underperformance of Socially Responsible Investing (SRI) stocks have tended to focus on the impact of negative screening by SRI investors of 'sin' stocks: a decrease in the size of the investor base produces a neglect effect associated with exclusionary screening, lower demand for 'sin' securities, a negative effect

\footnotetext{
1 Our sample period 2007-2012 is larger than those of the cited papers and therefore we can draw comparisons with their results. It would be interesting to extend our sample period to more recent years, but access to more recent data was not available to us given our funding and the agreements with Co-Star.
} 
on prices and a positive effect on returns. Nevertheless, the growing body of work on the performance of SRI securitized funds has found mixed results; see, among others, Bauer et al (2005), Renneboog et al (2008a, 2008b), Nollet, Filis and Mitrokostas (2016) and Shen et al. (2016). In the same spirit of the last two cited papers, our work aims to better interpret the empirically observed non-linearity in the relationship between performance and SRI. Interestingly for the existing literature on Real Estate eco-certifications and on Real Estate Investment Trusts (REITs), we obtain the novel result that a "green winner's curse", rather than buyer type effects or a REIT premium, explains the observed price premium for Energy Star certified Class A offices.

Our findings can be broadly summarized as follows. A perhaps surprising finding is that, in the high quality market segment, eco-certified office space has become part of the mainstream and is no longer a niche product. Eco-certified office space has accounted for almost half of all Class A office space transacted since 2007. In addition, exploiting CoStar data on investors' market shares, we find evidence for the existence of eco-investors (i.e. investors that are positively screening eco-certified office assets): a number of investors have only acquired eco-certified assets in the study period, while others have allocated the vast majority of the expenditure on Class A office to eco-certified offices. In line with previous hedonic studies, we find significant positive price premiums for some eco-certified office properties. However, this is only the case for space that is dual certified by LEED and Energy Star. When market share is included as a control in the hedonic estimations, there is no significant price premium for LEED or Energy Star certified stock. Our interpretation of this finding is that higher bids by eco-investors are a significant determinant of the observed price premium for eco-certified space. Our analysis indicates that obtaining a higher market share entails that the investor pays a higher purchase price for each percent of additional market share and that the magnitude of this premium is considerably higher for eco-certified assets acquired by investors with a high market share of eco-certified Class A offices, thereby indicating evidence of a winner curse for ecoinvestors. 
The remainder of the paper is organized as follows. In the next section, we discuss related research on the price effects of screening and of eco-certification in commercial real estate markets. Drawing upon auction theory, the subsequent section outlines a theoretical model of optimal bidding behavior and expected price effects. Data description and empirical analysis follow, together with detailed discussion of the econometric modeling and results. Finally, conclusions are drawn.

\section{Background and Literature Review}

Typically, eco-certifications are awarded by a third party to products with a reduced environmental impact compared to a conventional product. In US commercial real estate markets, the two most common voluntary programs are LEED and Energy Star. The LEED Green Building Rating System, developed by the US Green Building Council, consists of a set of standards for the assessment of environmentally sustainable construction. A range of similar rating schemes have emerged in most advanced economies. Typically, the rating systems focus on six broad categories related to: sustainability of location, water efficiency, energy and atmosphere, materials and resources, indoor environmental quality and innovation and design process. There are different levels of LEED accreditation based upon a scoring founded upon the six major categories listed above. In LEED 2009 for new construction and major renovations for commercial premises, buildings may qualify for four levels of certification: Certified, Silver, Gold and Platinum. The Energy Star program tends to be more commonly used for existing buildings and is an assessment of buildings' energy performance. Energy Star accreditation reflects relative energy efficiency and environmental performance since only buildings that are in the top quartile of energy efficiency are eligible for Energy Star accreditation. As our data will show, significant proportion of the buildings (and a larger proportion of space) is dual certified having an Energy Star certification in addition to LEED certification. Recent versions of LEED certification protocols require a minimum Energy Star rating, for example a rating of 65 for existing buildings applying for the LEED-EB label. 
There is a growing body of evidence that occupiers of, and investors in, buildings with better environmental performance can obtain a range of benefits. Owners, developers and/or occupiers can benefit from subsidies, tax reliefs and reduced regulatory barriers that have been offered in many jurisdictions. In addition to the above, the other significant tangible benefit to occupiers is lower utility costs regarding energy and water use. More difficult to measure benefits tend to be associated with productivity improvements (lower staff turnover, absenteeism, higher outputs inter alia), reduced obsolescence, lower regulatory risks and reputational rewards. Kats (2003), Singh et al. (2010), and Turban and Greening (1997) are among those showing that enhanced performance can come from energy efficiency, water efficiency, higher-quality outputs, and improved employee productivity (and retention and recruiting). Green buildings may provide other benefits to their owners, including serving as a hedge against climate, regulatory, or other environmental risks. See, for example, Jackson (2010), Deng, Li, and Quigley (2012), Kahn and Kok (2014), Kahn, Kok, and Quigley (2014).

Advantages for investors and developers tend to fall into similar categories. The green building literature has investigated geographical diffusion (see Fuerst, 2009; Choi, 2010; Kok, McGraw and Quigley, 2011, 2012), benefits for different types of occupiers (see Fuerst and McAllister, 2009; Eichholtz, Kok and Quigley, 2009) and referred to building buyers, tenants, and employees (Singh et al. 2010) as well as the owning firm's customers and investors (Eichholtz, Kok and Yonder 2012; Chegut, Eichholtz and Kok 2014) as being stakeholders who might value the green building signal. The policies towards the certification of green building can therefore be understood as an effort to better align the private costs of buildings with their social costs, where the certification process can verify difficult-to-observe improvements to building performance and its footprint, which might include energy efficiency, indoor air quality, or construction processes; see, among others, Kotchen (2006), Potoski and Prakash (2009), Fuerst, Kontokosta, and McAllister (2014), see also Brounen and Kok (2011) and Bond and Devine (2016a, 2016b) for related research on the role played by eco-certifications in the residential sector. 
As already mentioned in the introduction, price premiums could potentially offset some of these benefits, but due to problems of data availability the performance of investors who pay these price premiums has not been evaluated by the previous research; our paper takes a first step in this direction. Implicit in the research question addressed in this paper is an assumption that investor demand affects prices. Under the efficient markets hypothesis, investor demand should not matter since prices encapsulate the present value of the cash flow generated by the asset and given this horizontal demand curve assumption, investors can buy or sell any amount of a security without affecting its price. However, while in an efficient market clientele effects should not exist, there are numerous studies on securities markets demonstrating that they do. In commercial real estate markets, it is almost axiomatic that deviations from perfect market assumptions are substantially larger. Thin trading, high search costs, information asymmetries, heterogeneous assets and expectations all increase potential clientele effects. Indeed, segmentation is also often highlighted between investor types. Short-hand clientele investor categories such as institution/noninstitutional and core/value/opportunistic reflect variations in risk preferences amongst investor groups; indeed, assets are also classified in the same way.

There has been limited work on clientele effects in commercial real estate markets. Benjamin et al. (2008) found little evidence of a persistent premium for Real Estate Investment Trusts (REITs) over time finding evidence of an effect in a small number of years; research by Hardin and Wolverton (1999), Lambson, McQueen and Slade (2004) and - drawing upon a much larger sample of transactions - Ling and Petrova (2010) find evidence that tax-motivated, out-of-state and REITs buyers pay significantly more than instate buyers. Akin et al. (2013) looked at similar issues using more robust repeat-sales methods. An issue with this body of work is the tendency to simply classify buyers into REIT and non-REIT buyers. For Class A investment assets, in addition to long established institutional investors such as occupational pension funds and insurance companies, REITs must compete with other types of real estate investment organisations who have become increasingly prominent. Sovereign wealth funds, specialist open and closed end real estate funds, investment banks, specialist real estate investment managers, private equity groups 
and endowment funds have emerged as significant market participants with a number of these organisations creating significant operational platforms to execute real estate investment strategies. Whilst the premium price, or premium property, conundrum can be difficult to resolve, there are a priori reasons to expect clientele effects for eco-certified real estate assets. As widely argued by the cited literature, these may be motivated either by a "green glow" benefit, or expected higher investment performance of eco-certified assets or a blend of both. Hence, market segmentation may occur as eco-certified and noncertified assets are no longer perfect substitutes for a group of investors. As mentioned in the introduction, our specific contribution to the debate over REIT premium is to show that, in the market for eco-certified assets, the REIT premium can be interpreted as the clientele effect of eco-investors. In the next section, we set out the theoretical model in order to obtain theoretical predictions on the relationship between market concentration and asset prices. The theoretical predictions will then be tested in the subsequent econometric analysis.

\section{Theoretical Model}

We model a setting in which different investors bid competitively in a first-price sealed auction, which previous research shows to be a widely used method of institutional-grade commercial real estate disposal/acquisition in the US. ${ }^{2}$ As standard in the auction literature, we assume rational agents and obtain the investors' optimal bidding strategies through the concept of Nash Equilibrium. As discussed in the introduction, the value of eco-certified buildings may entail both a private dimension and a common one. We model these two dimensions in a simplified manner. We assume that different investors agree on the expected cash flows generated by the asset, but discount the cash flows at different discount rates. The fact that different investors have homogenous expectations about the future cash

\footnotetext{
2 An alternative type of selling mechanism could be a sequential auction, where investors can bid repeatedly for the same asset. Under the assumption of our model that the same group of investors bid for a number of assets, our main theoretical predictions would apply to that case as well.
} 
flows captures the dimension of the value of the asset that is common. The fact that different investors discount the cash flows at different rates reflects differences in cost of capital, risk and time preferences among investors, implying that their private appraisal of an asset's investment value may differ.

Specifically, we model a large number of investors bidding for a real estate asset. Investors agree on an expected cash flow $C$ generated by the asset but have different private discount rates $r_{i}{ }^{3}$ We assume that investors do not know exactly the private discount rate of their competitors but are correct about its distribution. We assume a uniform distribution of discount rates in order to simplify the analysis. Using a perpetuity formula, as standard in real estate valuation, we obtain the private value that each investor gives to the asset

$$
v_{i}=C / r_{i}
$$

We define $\max (v)$ as the maximum common value that any investor $i$ would be willing to pay for the asset - in other words the value obtained when the discount rate equals the internal rate of return (irr), such that an investor paying $\max (v)$ for the asset makes zero profit, hence:

$$
\max (v)=C / i r r
$$

Dividing $v_{i}$ by $\max (v)$ we obtain the normalized private value and we label it $w_{i}$, where

$$
w_{i}=v_{i} / \max \left(v_{i}\right)
$$

\footnotetext{
${ }^{3}$ It is a standard assumption in the real estate literature that investors value assets given different discount rates. In our case, this is the simplest modelling strategy in order to model investors that have different private values for the contended assets.
} 
and $w_{i}$ is uniformly distributed between 0 and 1 . Given this normalization, we can model a first-price auction where each investor bids for the asset given a private value between 0 and 1 , where private values are uniformly distributed.

Through standard results in auction theory (see for example Matthews (1995)) we obtain the optimal individual bid $b_{i}$ in a Nash Equilibrium:

$$
b_{i}=\left(\frac{N-1}{N}\right) w_{i}
$$

According to (4), investors find optimal to bid less than their private value, but as the number of competitors increases, individual bids become closer to private values.

We are interested in analyzing a setting where investors bid for a number of assets over a number of years and understanding how optimal individual bids may translate into higher numbers of wins for some investors leading to market concentration. For the rest of the analysis, we assume that the observed market share of one investor equals the probability of being the highest bidder in an auction. This assumption holds true if the same set of investors bids for a given number of buildings, which fits our empirical case of institutional investors in Class A offices.

Referring to Matthews (1995), the probability of being the investor with highest private value $w_{l}$ is given by the following expression

$$
f\left(w_{1}\right)=N w^{N-1} .
$$

Considering that the individual investor's market share equals the probability of being the investor with the highest bid, i.e. with the highest private value, we define the market share of an investor $i$ as $M S_{i}=f\left(w_{l}=w_{i}\right)$. From (5) we obtain that 


$$
w_{i}=\left(\frac{M S_{i}}{N}\right)^{\frac{1}{N-1}}
$$

Expression (6) implies that from the observed market share of an investor, we can recover the private value and, more precisely, the discount rate of this investor. Reexpressing (6) through (1) and (2) we obtain:

$$
\frac{i r r}{r_{i}}=\left(\frac{M S_{i}}{N}\right)^{\frac{1}{N-1}}
$$

Expression (7) implies that the lower is the discount rate $r_{i}$ of an investor and the higher the investor can afford to bid, hence the higher is the investor's market share. The incentive for an investor to be a frequent winner and therefore to gain a substantial market share is given by the difference between the private value (3) and the implied bid (4). We define this difference the private gain of an investor. It is immediate to verify that the private gain equals to

$$
w_{i}-b_{i}=\frac{1}{N}\left(\frac{M S_{i}}{N}\right)^{\frac{1}{N-1}}
$$

We verify that at any given market share $M S_{i}$, the private gain decreases as the number of competitors $N$ increases, because the more competitive is the auction and the closer to the private value one has to bid to maintain a given market share.

We also notice that, fixing the number of competitors $N$, the private gain increases with the market share. This is because the higher is the private value $w_{i}$-hence the market share by expression (6) - and the less close to the private value one has to bid in order to win, as suggested by expression (4).

We also investigate an alternative notion of investors' gain, namely the percentage difference between the (normalized) maximum common value and the individual bid ( 1 $\left.b_{i}\right) / 1$. We define this difference as the market gain of an investor. Since $\max (v)$ is defined 
as the asset price such that an investor would make null profit, the market gain is a measure of the return on the investment, given a value $\max (v)$ that is agreed by the market participants. Re-expressing (4) through (1) and (2), we obtain that

$$
b_{i}=\frac{(N-1) i r r}{N r_{i}} .
$$

We notice that expression (9) increases in the ratio $i r r / r_{i}$, because the lower is the discount rate $r_{i}$, and the higher the investor can afford to bid. As already noted, this also implies through (7) that the lower is the discount rate $r_{i}$ and the more often the investor wins, hence the higher is the market share. We also notice that, as the individual bid increases with the market share, the higher is the individual market share and the closer to the maximum common value is, on average, the price at which the investor buys the asset (the winning bid). This implies that the investor's market gain decreases with the market share, i.e. a winner's curse.

Summarizing, our theoretical framework shows that, if investors bid rationally, investors that win more often than others do so, on average, because they can afford to bid higher. This different private element is captured by the heterogeneous discount factor, which may broadly proxy for different economic factors, for example different costs of capital or different risk preferences. In addition, our theoretical results show that investors who bid higher and win more often make, on average, a lower rate of return (measured as the extra percentage on the zero profit rate) on the single asset, with respect to investors that win less often but pay lower prices.

\section{Numerical simulations}

We analyze the numerical predictions of our theoretical model for the case of 15 investors $N=15$. This will be shown to be the number of strategic players suggested by the results in the empirical section. Figure 1 shows how an investor's private value $w_{i}$ and winning bid $b_{i}$, computed by (6) and (4), vary with the market share. Given the theoretical 
set-up, $b_{i}$ should be interpreted as the expected or average winning bid of an investor, given her market share. The numerical results show that an investor with a $1 \%$ market share is bidding approximately $55 \%$ of the maximum common value, while an investor with a $5 \%$ market share is bidding approximately $62 \%$ of the maximum common value.

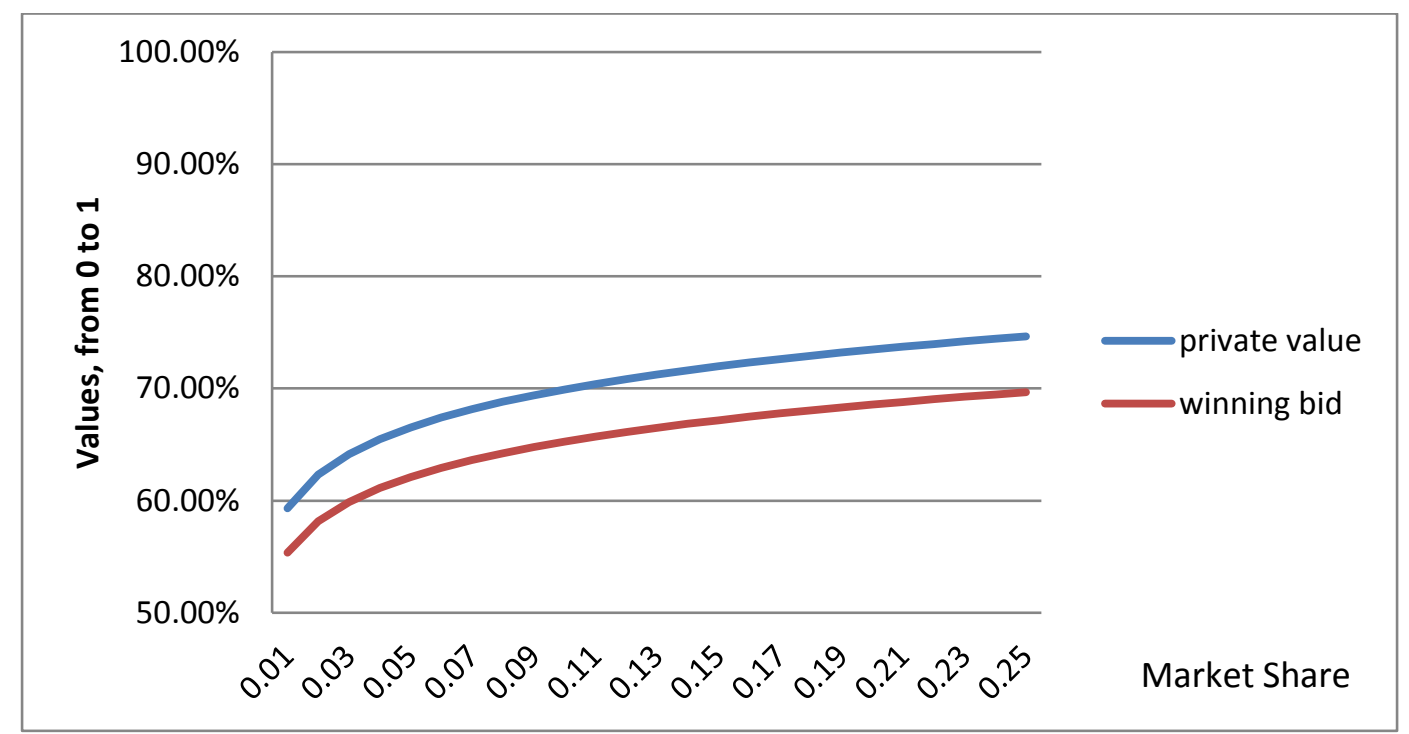

Figure 1: Private values and winning bids

Despite the concave behavior shown in Figure 1, we verify that a percentage increase in the market share implies a constant percentage increase in the winning bid. Figure 2 shows, by plotting the winning bid $b_{i}$ against percentage increases in the market share, that the elasticity of the winning bid with respect to the market share, for the case of $N=15$ (which will be the number of strategic investors justified by our empirical results), is constant and equal to $0.07 \%$. 


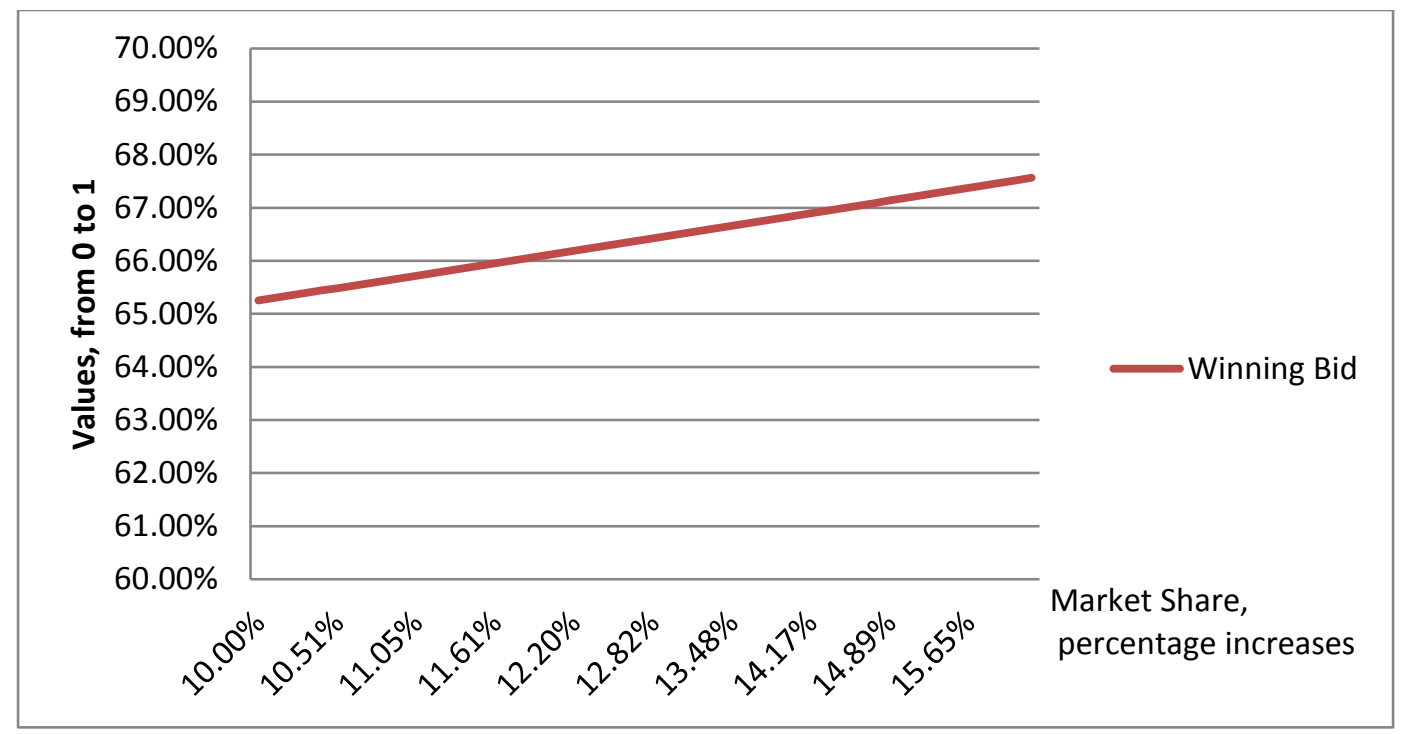

Figure 2: Elasticity of the winning bid, with respect to the market share

Figure 3 shows how the difference between an investor's private value $w_{i}$ and winning bid $b_{i}$, namely the private gain, changes with the market share, as computed by (8). The numerical results show that the private gain does not vary significantly for different market shares. Therefore, according to the model it does not appear that, given their private value (which can be interpreted as a reservation price), investors that win less often pay significantly less. 


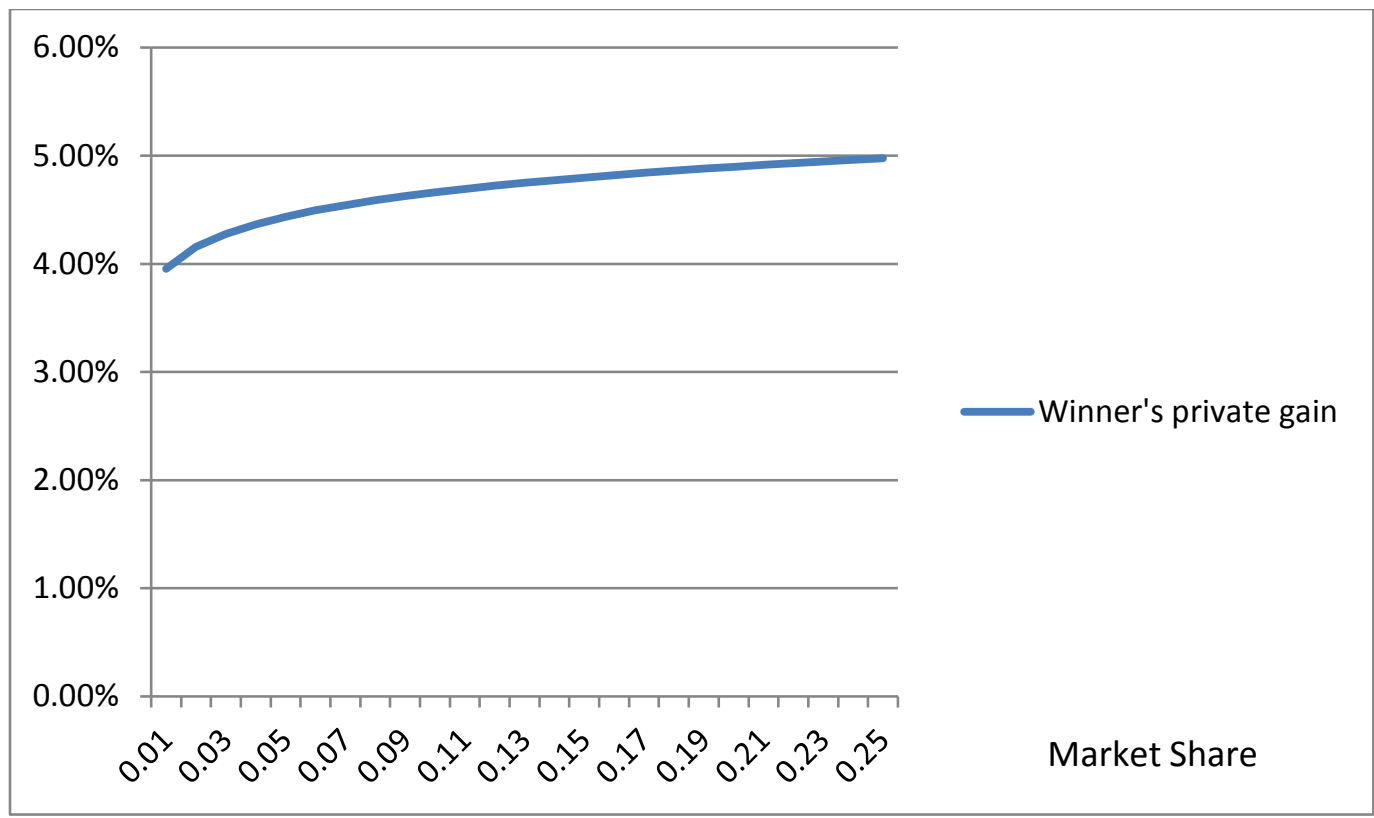

Figure 3: Winner's private gain

Figure 4 shows how the difference between 1 (the normalized maximum common value) and an investors' winning bid $b_{i}$, namely the market gain, changes with the market share, as computed by (4) and (6). Consistently with figure 1, figure 4 shows that an investor with a $1 \%$ market share is paying approximately $45 \%$ less than the maximum common value for the asset, while an investor with a $5 \%$ market share is paying $38 \%$ less than the maximum common value. We also notice that an increase above $20 \%$ of the market share has only a very small effect on the market gain. Figure 4 shows also how the ratio $r_{i} /$ irr varies with the market share of an investor, as obtained by (7). The numerical results show that the private value of an investor with a $1 \%$ market share is obtained by discounting cash flows at a rate equal to the $68 \%$ of the $i r r$, while the private value of an investor with a $5 \%$ market share is obtained by discounting cash flows at a lower rate equal to the $50 \%$ of the irr. We also notice that the ratio $r_{i} /$ irr varies significantly with increases above $20 \%$ of the market share and eventually converges to the market gain. 


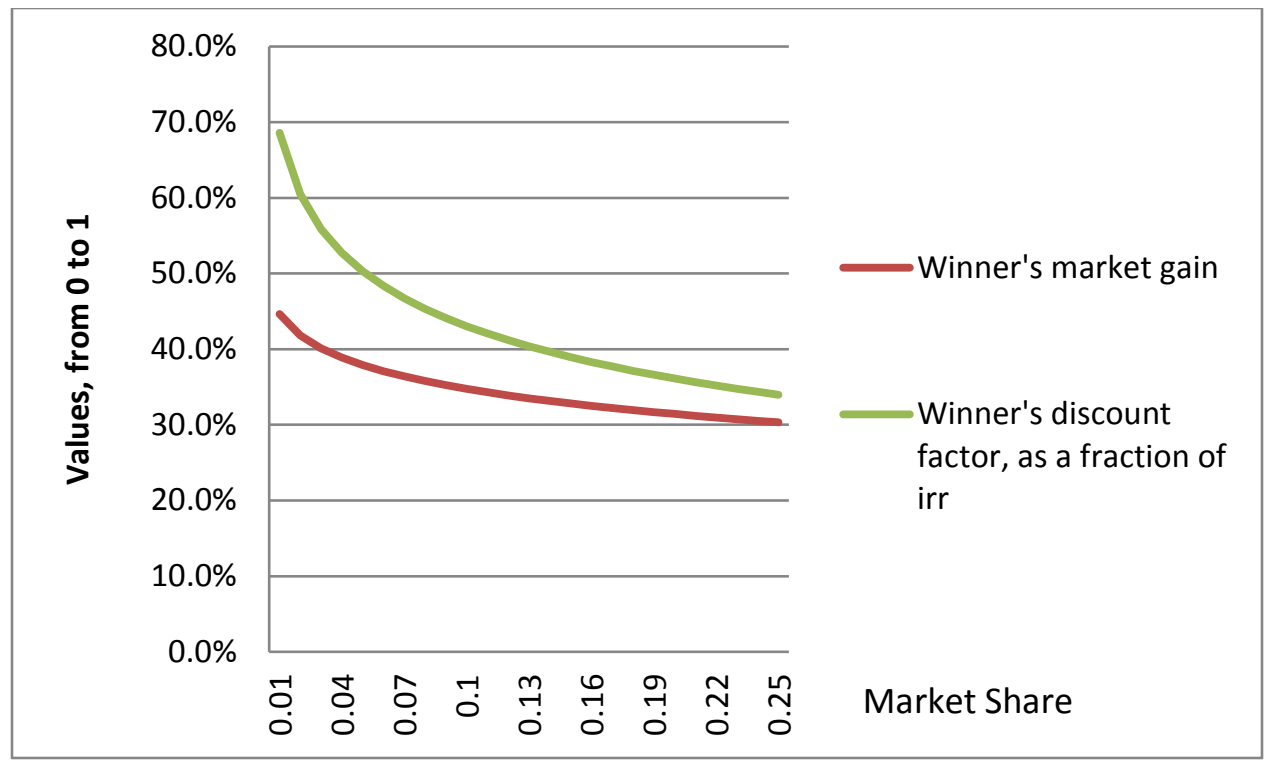

Figure 4: Market gain and discount factor

\section{Testable implications}

The focus of our empirical exercise is to identify the determinants of the price paid for eco-certified buildings. Is it the case that investors in eco-certified buildings systematically over-pay for their assets? If yes, is this due to strategic bidding in an auction setting? Those are the questions that we address.

In our empirical analysis, we observe the price paid, i.e. the winning bid, and we explain this price with a hedonic model. We interpret the price difference between two buildings with the same hedonic features as a premium. Our theoretical model predicts that, other things equal, an increase in market share increases the winning bid and therefore the price premium. This can be easily seen by plugging (7) into (9) as we obtain that

$$
b_{i}=\frac{(N-1)}{N}\left(\frac{M S_{i}}{N}\right)^{\frac{1}{N-1}} .
$$


Since our empirical hedonic model will control for the features of the building, the first testable implication of our model is that the price premium increases with the market share. Specifically, the empirical model will give a result in terms of elasticity and will predict, as shown by Figure 2, that an increase of $1 \%$ in the market share is associated to a $0.07 \%$ increase in the price premium, leading us to believe that $N=15$ players is a good approximation of the number of strategic players in commercial real estate auctions. The second prediction that can be inferred by (10) is that the higher is the number of competitors $N$ and the lower is the marginal impact of the market share on the price premium, since the probability of winning by placing strategically optimal bids is lower. We empirically test those predictions in the following sections.

\section{Data}

The empirical analysis draws on CoStar's comprehensive national commercial real estate database which includes approximately 43 billion square feet of commercial space in more than two million properties making it the largest available real estate database in the United States. For researchers, it has become an increasingly important source of data on real estate assets and transactions. In total, we have collected information on just over 3000 transactions of which 2,734 were usable. This dataset comprises all recorded sales of Class A office buildings where prices are in the data set in the five-year period from Q1 2007 through Q1 2012.

The summary statistics are displayed in Table 1. There are clearly some differences between eco-certified and non-certified Class A office buildings. LEED certified offices tend to be newer - the median age of LEED certified offices is five years. The comparable figure for the non-certified offices is 22 . While there is relatively little difference between buildings with Energy Star label, dual certified and the non-certified sample in terms of age, the former tend to be dominated by tall buildings suggesting that they are mainly located in CBD locations. This is supported by the fact that Energy Star and dual certified 
also tend to be much larger than non-certified offices buildings. Whilst there is little difference in occupancy rates, without controlling for the differences between the samples, median sale prices are substantially higher for eco-certified offices. However, compared to previous studies the pattern for LEED offices seems to have

Table 1: Summary Statistics

\begin{tabular}{|c|c|c|c|c|c|}
\hline Summary Statistics & & & & & \\
\hline Non-certified & Price (\$psf) & Stories & Size (sq ft) & Age (yrs) & $\%$ Leased \\
\hline Mean & 224 & 7.3 & 171,918 & 22.9 & 84.8 \\
\hline Median & 184 & 4.0 & 115,000 & 23.0 & 92.3 \\
\hline Standard deviation & 171 & 8.2 & 225,302 & 18.3 & 20 \\
\hline Observations & 1863 & 1863 & 1863 & 1863 & 1863 \\
\hline Energy Star certified & Price (\$psf) & Stories & Size (sq ft) & Age (yrs) & $\%$ Leased \\
\hline Mean & 277 & 13.2 & 311,230 & 26.7 & 85.7 \\
\hline Median & 236 & 9.0 & 207,549 & 25.0 & 90.1 \\
\hline Standard deviation & 162 & 11.7 & 309,092 & 17.5 & 14.7 \\
\hline Observations & 537 & 537 & 537 & 537 & 537 \\
\hline LEED certified & Price (\$psf) & Stories & Size (sq ft) & Age (yrs) & $\%$ Leased \\
\hline Mean & 304 & 8.8 & 247,903 & 14.4 & 90.6 \\
\hline Median & 260 & 6.0 & 183,657 & 5.0 & 99.2 \\
\hline Standard deviation & 186 & 8.4 & 297,701 & 19.8 & 16.1 \\
\hline Observations & 88 & 88 & 88 & 88 & 88 \\
\hline Dual certified & Price (\$psf) & Stories & Size (sq ft) & Age (yrs) & $\%$ Leased \\
\hline Mean & 344 & 19.7 & 465,447 & 23.8 & 87.3 \\
\hline Median & 312 & 15.0 & 334,794 & 23.0 & 91.0 \\
\hline Standard deviation & 164 & 15.4 & 378,529 & 17.7 & 15.7 \\
\hline Observations & 246 & 246 & 246 & 246 & 246 \\
\hline
\end{tabular}

changed substantially. Confirming previous research, dual certified offices seem to comprise mainly of prestige offices. Compared even to LEED and Energy Star, typically they sell for more and are larger and taller. 
The names of buyers were provided with each transaction. A range of categories of buyers were specified by the research team. These included; insurance group, investment bank, major financial services group, pension fund, private equity group, private real estate company, REIT and specialist real estate asset manager. Buyers that had purchased less than five assets in the sample were labelled 'low volume buyers' and not categorised. Categorization was largely based upon an analysis of the content of the web site of the organization. We would acknowledge that a number of organizations offered a range of real estate-related activities and categorization was not always straightforward. It is also possible that for a proportion of single asset buyers were special purpose vehicles owned by a large-scale real estate investors set up specifically to acquire and hold the asset.

The breakdown of the buyers of Class A office investments indicates the changing nature of the real estate investment markets with the emergence of private investment organisations and the relative decline of traditional investing institutions such as pension funds and insurance companies. Of a total of 2,734 usable transactions, over $58 \%$ involved low volume real estate buyers. As noted above, this category consisted of buyers that had a market share ${ }^{4}$ of less than $0.15 \%$ in that they had acquired four or fewer assets out of the total of 2,734. Collectively, insurance companies, investment banks, pension funds and major financial services groups who had purchased five or more assets accounted for just over 3\% of all transactions. Specialist real estate asset managers (11.8\%) and REITs $(18.8 \%)$ were the biggest categories of large-scale investors. Private equity groups (3.5\%) and private real estate companies $(6.1 \%)$ were also significant large-scale investors.

Figure 5 provides a breakdown of the transaction volumes for eco-certified and noncertified Class A office space over the period. Not surprisingly, associated with the financial crisis, the dominant structural pattern is a sharp fall in transaction volumes after 2007 for both eco-certified and non-certified offices. While this is followed by an upturn in transaction volumes in 2010 and 2011, the levels of 2007 are not achieved again. In

\footnotetext{
${ }^{4}$ We define market share as the number of transactions as a proportion of total transactions in the US Class A office market.
} 
2007, eco-certified Class A office space accounted for nearly 50\% of all transacted Class A office space. In 2011, the comparable figure was approximately $43 \%$. When the data is disaggregated in the three main categories, it is clear that in terms of floor space Energy Star certified office space has accounted for nearly $57 \%$ of eco-certified Class A office space. A substantial proportion of the remainder (36\%) is accounted for by dual certified office space. This increases in 2011 to account for over $41 \%$ of all Class A eco-certified office space transacted. Offices with only the LEED certification are the smallest segment. In 2007, they accounted for around 3\% of all eco-certified space transacted. After 2007, this figure increased to approximately over 13\%. Given the relatively low level of trading in LEED-only certified Class A office space especially regarding the number of properties transacted, it is unlikely that significant concentrations of buyers will be identified.
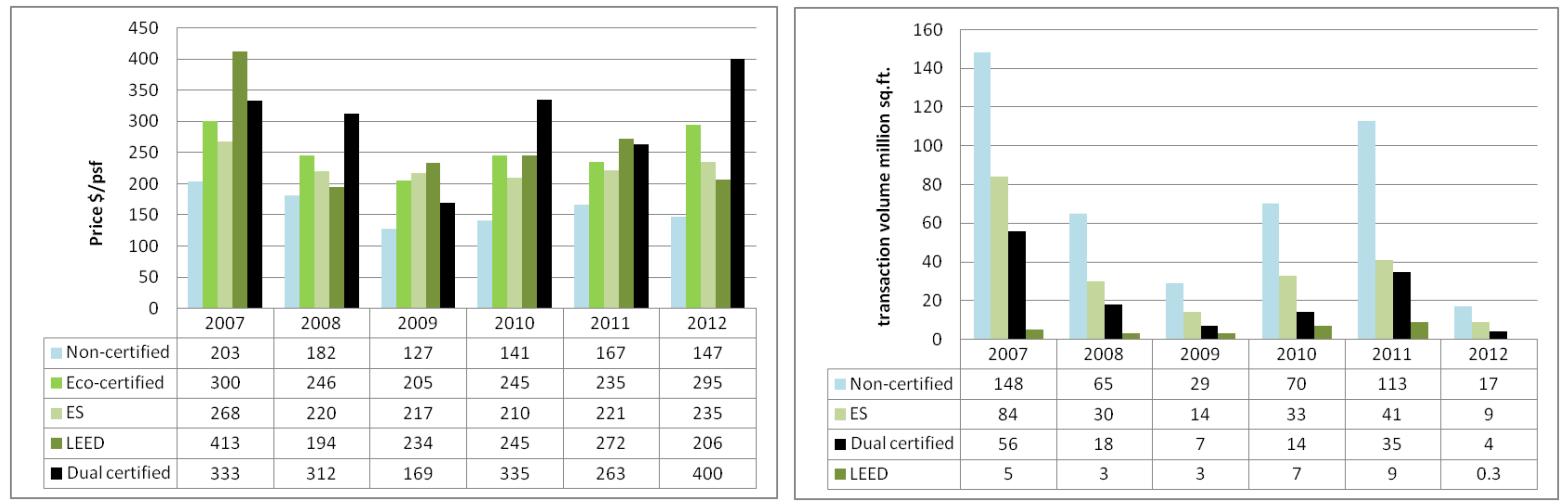

Figure 5: $\quad$ Sale Volumes and Prices for US Class A Offices 2007-2012

Given that there is no commonly recognized definition of 'eco-investors', we use a number of criteria to identify investors that have acquired large amounts of eco-certified Class A office space compared to non-certified Class A office space. Given the fact that Energy Star and dual certified offices are more likely to be large assets, it is possible that the inherently 'lumpy' nature of real estate investment may mean that investors are misidentified as eco-investors e.g. an investor who buys a single large, incidentally (from the investor's perspective) eco-certified, trophy asset may appear to be an eco-investor. As a result, we select investors who have purchased large amounts of eco-certified office space 
both in absolute and relative terms. The definition of an 'eco-investor' used in this analysis is based on the share of eco-certified properties an investment company acquires in relation to all properties they acquired during the study period 2007-2012. If at least half of the office space acquired by an investor is eco-certified, we consider this investor an ecoinvestor. To avoid spurious inference caused by low volume buyers buying a small number of Class A office properties that happen to be eco-certified, we impose a minimum condition of three eco-certified properties acquired in the 2007-12 period in order for an investor to be included in this category.

Figure 6 illustrates the association between an investor's market share in the eco-certified Class A office investment market and the total Class A office investment market. Companies above the regression line are eco-investors with a higher market share in the eco-certified market than their total market share would suggest. Conversely, companies below the line are investing less in the eco-certified market than their position in the overall market would suggest. As expected, market concentration in the overall market is lower than it is in the smaller market for eco-certified buildings. The regression line and the scaling of the two axes take these general differences in market shares into account. Using this simple graph, a group of relatively large eco-investors emerges along or above the regression line with the three largest eco-investors (Beacon Capital, Hines and JP Morgan Chase) in the left upper quadrant forming a distinct sub-group. 


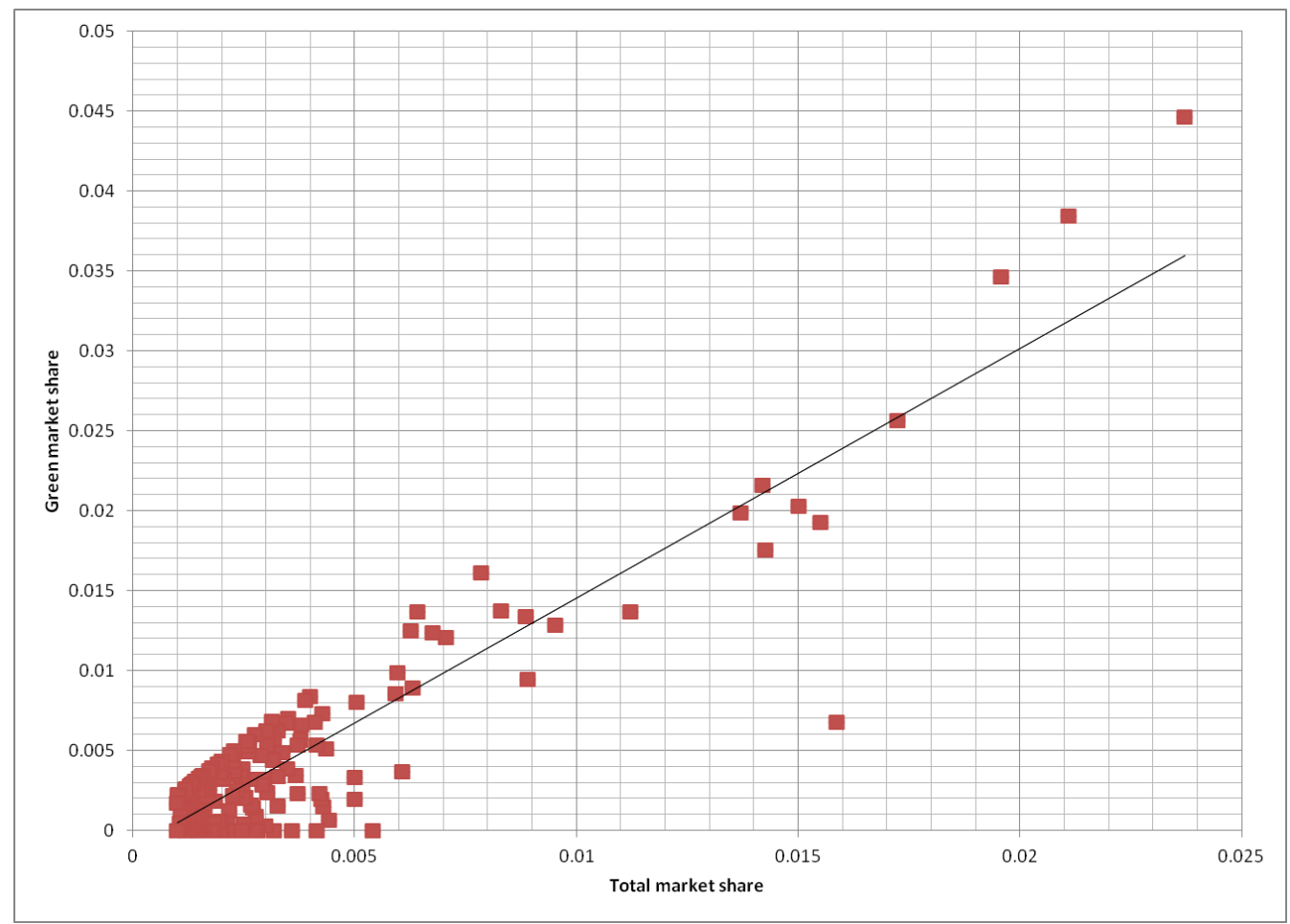

Figure 6: Total Market Share vs. 'Green’ Market Share (as of March 2012)

The group of eco-investors that we identified using the criteria described above accounts for a significant share of purchases of eco-certified properties. This group bought $41 \%$ (218 million sq. ft.) of all Energy Star, LEED or dual certified Class A office properties but only $12 \%$ (54 million sq. ft.) of non-certified Class A office assets. Figure 7 confirms this trend by showing the cumulative annual acquisitions of the Top 20 among eco-investors. Perhaps not surprisingly, eco-investors' commitment of capital to eco-certified assets, in particular to dual-certified assets, has outpaced their purchases of non-certified assets by far. Nevertheless, this finding is important in that it confirms that the largest buyers of ecocertified assets are not simply "accidental eco-investors", i.e. big overall buyers in the institutional-grade office market but rather a distinct group of large investors predominantly targeting eco-certified assets. 


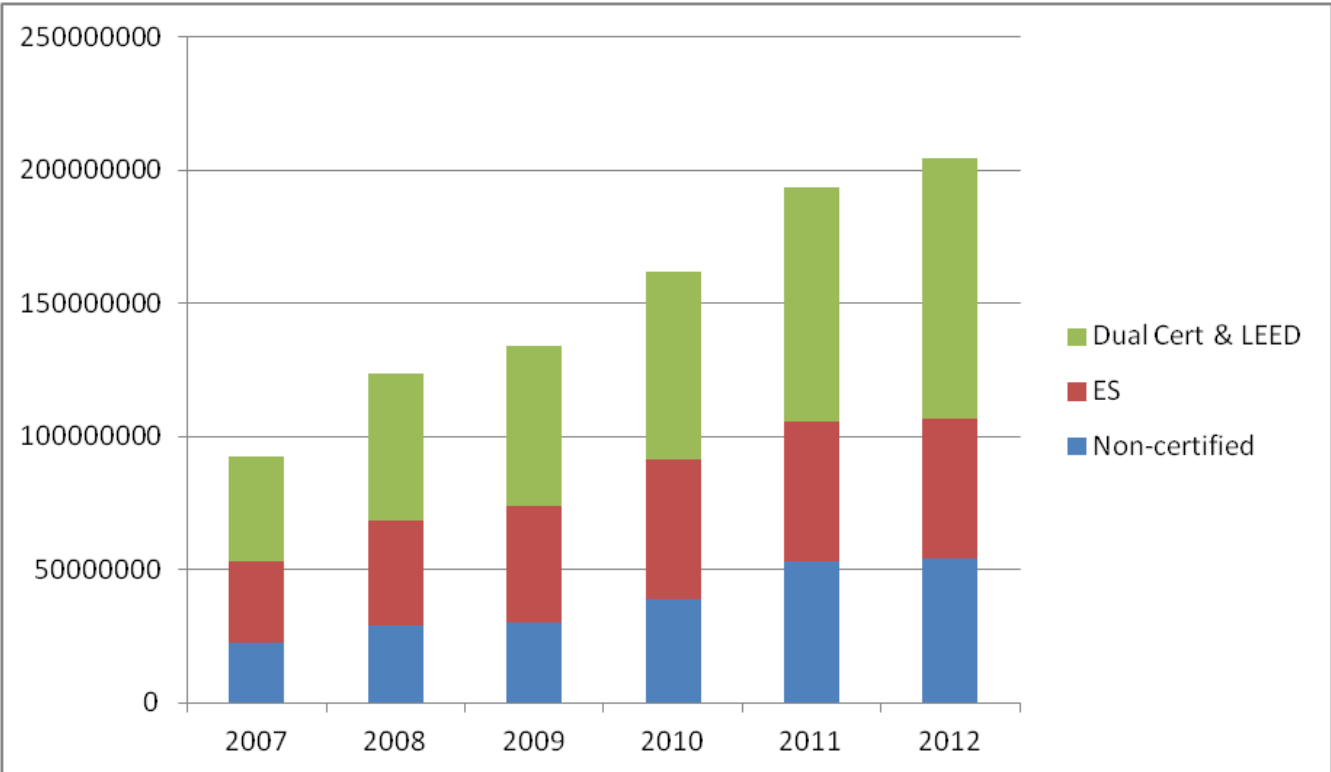

Figure 7: Cumulative square footage of Class A office space acquired by Top 20 Eco-Investors by type of certification

\section{Empirical Analysis}

We use a standard hedonic framework in our study primarily to isolate the effect of the main price determinants - size, age, location, vacancy rate, buyer type, time of sale etc. Rosen's (1974) full specification of the hedonic method is a two-stage process where the first stage estimates the hedonic price function by regressing the transaction price on a number of price determinants. In the second stage, the marginal willingness-to-pay parameters are recovered from the implicit price function estimated in the first stage, taking into account the buyer's budget constraints and utility level. These can be estimated by using the marginal price of the first stage in this model. The second stage is inherently more difficult to estimate and prone to bias and misspecification problems. This has led many researchers in more recent studies to use a single-stage reduced form model.

Our empirical strategy is to quantify the effects of environmental certification on sale prices, initially without considering the effects of auctions and bids, by using indicator 
variables that capture whether a building has an Energy Star, LEED label or both. A positive coefficient of these variables is expected indicating that, on average, environmentally certified offices sell for higher prices than non-certified offices. In addition to mitigating the effects of extreme values, the log-log specification of the hedonic model allows us to interpret the coefficients in terms of average percentage premiums. A summary specification of our model is then:

$\ln P=c+\beta_{1} \ln A+\beta_{2} \ln R+\beta_{3} \ln X+\beta_{4} B+\partial T+\varphi S+\omega G+\partial N \omega G+\partial N+\varepsilon(12)$

Where the transaction price per square foot of rentable office space on natural log scale is estimated as a function of building age $(A)$, years since last major refurbishment $(R)$ as well as a vector of physical characteristics $(X)$ that includes, among others, building height and total square footage, $(B)$ are buyer characteristics such as type of investment vehicle and company size. We have investor type - but not vehicle or company size - is this a cut and paste problem? $T$ is a set of quarterly time dummy variables and $S$ is a set of office submarket dummy variables. The parameters $\beta_{i}$ represent the constant elasticity of price with respect to each hedonic characteristic. The key variables $\omega$ and $\partial$ are the market shares of each buyer in the 'green' and the 'non-green' market respectively. To estimate the impact of market share on the price paid, we interact these variables with the dummy variables $G$ and $N$ which indicate an eco-certified and non eco-certified building respectively. In line with our theoretical exposition, we expect a positive and significant parameter estimate for the interaction term $\omega G$.

It is notable that few previous studies have identified a separate category of offices that had dual certification from Energy Star and LEED. This is a potentially significant limitation. In our sample, Energy Star certified space accounts for $56 \%$ of total certified space, the LEED label for $7 \%$ and dual certified buildings account for the remaining $36 \%$. Fuerst and McAllister (2011a) discuss the potential omitted variable problem that may result. They suggest that failure to include an interaction term or separate indicator variable for dual certified assets produces a negative bias in the estimates of the price effects of the 
individual eco-certificates. In the present analysis, we code dual certification as a separate variable, rather than applying a multiplicative interaction term, mainly to avoid collinearity problems.

To reduce any potential omitted variable bias - the 'premium property effect' identified in studies of REIT acquisition prices - we include a number of variables often associated with high quality, prestigious office buildings. It is possible that eco-certification price effects are in part due to the effects of other (unobserved) building attributes such as design quality, internal specification, facilities. Variables included in the hedonic specification are the presence of a fitness center, atrium, food services, signage inter alia. In addition, the use of submarkets as the location, the inclusion of distance from transit stations and the control for age, height and size of office should also control for the possibility that eco-certified offices may be more likely to be 'best-in-class'. While it is possible that eco-certified offices may have better quality tenants on leases that are attractive for the investor, these attributes may ultimately be related to eco-certification.

\section{Results}

The hedonic framework allows us to control for systematic differences between the ecocertified sample and the overall sample. It also allows us to control for the sub-samples acquired by eco-investors. Table 1 shows summary statistics and variable definitions. It is clear that the characteristics of the average eco-certified building are different from the overall sample. In particular, as noted above, eco-certified offices tend to be larger and taller. Detailed results for all model specifications can be found in Table 2. The estimated coefficients on the control variables are generally of the predicted sign and remain consistent across a range of model specifications. For example, the estimated coefficient on age and period since refurbishment is negative and statistically significant in line with our expectations. In line with previous studies, there is a positive relationship between price and height of the building (number of stories). As expected, there is also a significant 
positive relationship between plot area and price. Not surprisingly, there is a strong positive effect of occupancy rate on sale price per square foot. Some of the variables associated with prestige buildings tend to have the expected coefficients. All else equal, named buildings tend to sell at a premium of approximately 7\%. The presence of food services also tends to have positive price effect of approximately $6 \%$. Not surprisingly, all else equal, the distance from a transit station has a negative effect on sale price.

Turning to the variables of interest, Model 1 estimates that eco-certified buildings sell at a premium of approximately 5\% relative to non-certified buildings. It is notable that there is a strongly significant positive relationship between the investors' market share and the prices paid. This is consistent with large-scale investors in Class A office space paying higher prices in order to win bidding 'contests' for real estate assets. We then perform a number of robustness checks through different models' specifications. As we will describe in the remainder of this section, the estimated effect of investor market share remains consistent and significant in all models. More specifically, the empirical result of models 1,2 and 4 that the price elasticity with respect to the market share equals $0.07 \%$ can be rationalized by the numerical results of the theoretical model with 15 strategic bidders.

In Model 2, we investigate the extent to which premiums vary with type of eco-certificate and find some surprising results. LEED-only assets account for a relatively small proportion of total eco-certified Class A stock transacted and we find no statistically significant price effect for this type of certification. The estimated price premium for Energy Star certification is also statistically insignificant. This is an unexpected finding since previous studies ${ }^{5}$ have found a significant positive price effect for Energy Star certified offices; the reason for our novel result is that, differently from the previous studies, we control for the investors' market share. Those results lead us to think that it is the investor's market share to be driving the observed certification premiums.

\footnotetext{
5 Eichholtz, Kok and Quigley (2011), Wiley, Benefield and Johnson (2010), Fuerst and McAllister (2011a, 2011b) and Miller, Spivey and Florance (2008).
} 
Robustness Checks.

In order to more robustly check the extent to which eco-certification premiums are being affected by market share rather than eco-certification effects, we omit market share as a control variable in Model 3 whilst retaining the same specification. We find that the estimated price premiums increase and that the Energy Star price premium is significantly positive at around $9 \%$. Our interpretation of these findings is that bids by eco-investors are a significant determinant of the price premium for eco-certified space. In order to control for potential effects of buyer type, Model 4 includes dummy variables representing the different categories of investing organizations discussed above. The results remain broadly the same as Models 1 and 2. Most relevantly, again there is no statistically significant price premium for LEED or Energy Star certified Class A office investments. However, a price premium of $8 \%$ is estimated for dual certified Class A office investments. It is striking that there are no significant buyer-type effects. In particular, it is notable that there is no evidence to suggest that, all else equal, REIT buyers pay a price premium compared to other investing organizations.

In line with the theoretical model, we also expect that investors who acquired relatively high proportions of eco-certified stock will tend to have paid higher prices. In Model 4 we estimate the price effects of interacting asset certification (eco-certified or non-certified) and investors' market share of eco-certified and non-eco-certified Class A office transactions. The model estimates for the control variables are broadly similar to the previous models and again there is no significant price effect of buyer type. With regard to the effects of market share on price, the results are broadly consistent with expectations. There is a significant positive effect of market share of eco-certified of Class A offices on the price of eco-certified Class A office space. Essentially, the result suggests that the larger investors' market share of eco-certified Class A office space, the higher the price that they have paid. There is also a significant positive effect of market share of eco-certified of Class A offices on the price of non-certified Class A office space. However, the size of the effect is smaller. The fact that there is no significant relationship between market share of 
non-certified Class A office space and the price of eco-certified space is also consistent with eco-investors paying more for eco-certified space. Further support is provided by the fact that there is a significant positive effect of market share of non-certified Class A office space on the price of non-certified space - albeit that the size of the effect is much smaller compared to the effect of market share of eco-certified space on the price of eco-certified Class A office space.

The results support the theoretical prediction that an increase in the market share is associated with an increase in the price paid for an asset. More specifically, the empirical result of models 1, 2 and 4 that the price elasticity with respect to the market share equals $0.07 \%$ can be rationalized by the numerical results of the theoretical model with 15 strategic bidders. Moreover, the prediction of the theoretical model that a higher number of players reduces the marginal impact of the market share on the winning bid offers us an interpretation for the lower values of the price elasticity with respect to the market share in model 5, leading us to think that auctions for conventional buildings may be characterized by a higher number of potential bidders. 


\section{Table 2: Results of Hedonic Modelling, Dependent Variable: (Log) Price\$ psf}

Model

Eco-certified

LEED certified

Energy Star certified

Dual certified

Named building

Office Park

Atrium

Corner lot

Restaurant

Signage

Fitness center

Food services

Bus line

Walk to transit

Street level retail

Part of mall

Age (squared)

Years since refurb (squared)

Number of stories

Total rentable floorspace

Land area

Occupancy rate

Insurance company

Investment bank

Low volume investor

Major financial services group

Pension fund

Private equity group

Private real estate company

REIT

Specialist real estate asset manager
(1)

(2)

(3)

(4)

(5)

0.047*

$\begin{array}{cc} & 0.026 \\ & 0.039 \\ & \mathbf{0 . 0 8 7} * \\ \mathbf{0 . 0 6 7} * * & \mathbf{0 . 0 6 7} * * \\ \mathbf{0 . 0 7 5} * * & \mathbf{0 . 0 7 5} * * \\ -0.041 & -0.044 \\ 0.025 & 0.025 \\ 0.026 & 0.024 \\ 0.009 & 0.009 \\ 0.041 & 0.040 \\ \mathbf{0 . 0 6 0} * & \mathbf{0 . 0 6 1} * * \\ \mathbf{- 0 . 0 6 0} * & \mathbf{- . 0 . 0 6 0} * \\ \mathbf{- 0 . 0 6 7} * * & \mathbf{- 0 . 0 6 7} * * * \\ -0.033 & -0.033 \\ 0.133 & 0.130 \\ \mathbf{- 0 . 0 4 1} * * * & \mathbf{- 0 . 0 4 4} * * * \\ \mathbf{- 0 . 0 0 8 *} & \mathbf{- 0 . 0 0 8 *} \\ \mathbf{0 . 0 7 4} * & \mathbf{0 . 0 7 3} * \\ \mathbf{- 0 . 0 7 2} * & \mathbf{- 0 . 0 7 3} * * \\ \mathbf{0 . 0 3 1} * & \mathbf{0 . 0 3 1 *} \\ \mathbf{0 . 1 7 6} * * * & \mathbf{0 . 1 7 7 * * *}\end{array}$

0.036

0.038

$0.081 *$

\begin{tabular}{|c|c|}
\hline $0.067 * *$ & $0.070 * *$ \\
\hline $0.075 * * *$ & $0.084 * * *$ \\
\hline-0.043 & -0.046 \\
\hline 0.024 & 0.022 \\
\hline 0.024 & 0.030 \\
\hline 0.010 & 0.009 \\
\hline 0.040 & $0.047 *$ \\
\hline $0.060 *$ & $0.062 * *$ \\
\hline$-0.061 *$ & $-0.070 *$ \\
\hline$-0.067 * * *$ & $-0.070 * * *$ \\
\hline-0.033 & -0.042 \\
\hline 0.131 & 0.16 \\
\hline$-0.043 * * *$ & $0.040 * * *$ \\
\hline$-0.008 *$ & $-0.008 *$ \\
\hline $0.073 *$ & $0.071 *$ \\
\hline$-0.072 *$ & -0.028 \\
\hline $0.032 *$ & 0.034* \\
\hline $0.178 * * *$ & $0.179 * *$ \\
\hline
\end{tabular}

Hold-out Hold-out

$-0.137 \quad-0.031$

$-0.030-0.071$

$0.087 \quad 0.140$

$0.107 \quad 0.161$

$-0.022 \quad 0.029$

$0.007 \quad 0.046$

$-0.002 \quad 0.084$

$-0.046 \quad 0.039$

$0.074 * * *$

(Log) Investor Market Share

$0.077 * * *$

$0.076 * * *$

$0.021 *$

(Log) Green market share and green building interaction

(Log) Green market share and conventional building

interaction

(Log) Conventional market share and green building interaction

(Log) Conventional market share and conventional building interaction

$-0.003$

$0.005 * *$

\begin{tabular}{|c|c|c|c|c|c|}
\hline Constant & $6.476 * * *$ & $6.500 * * *$ & $4.888 * * *$ & $6.492 * * *$ & $5.59 * * *$ \\
\hline Quarterly fixed effects & Yes & Yes & Yes & Yes & Yes \\
\hline Submarket fixed effects & Yes & Yes & Yes & Yes & Yes \\
\hline$N$ & 2734 & 2734 & 2734 & 2734 & 2734 \\
\hline$R^{2}$ & 0.67 & 0.67 & 0.65 & 0.67 & 0.67 \\
\hline adj. $R^{2}$ & 0.62 & 0.62 & 0.60 & 0.62 & 0.62 \\
\hline$A I C$ & 3416.6 & 3418.4 & 3590.9 & 3426.8 & 3461.5 \\
\hline$B I C$ & 5297.1 & 5310.7 & 5477.3 & 5366.4 & 5401.1 \\
\hline
\end{tabular}

$t$ statistics in parentheses ${ }^{*} p<0.05,{ }^{* *} p<0.01,{ }^{* * *} p<0.001$ 


\section{Conclusions}

The aims of the research were to investigate patterns of buying behavior in eco-certified Class A offices and to evaluate the effect of potential SRI-type screening on pricing. It is clear from this analysis that, in the Class A office market segment, eco-certified space has become part of the mainstream and is not a niche product in the Class A office sector. Ecocertified office space accounted for almost half of all Class A office space transacted between 2007 and 2012. The vast majority of this space comprises offices that are Energy Star or Energy Star and LEED certified. Offices with LEED-only certification have accounted for less than $10 \%$ of all Class A eco-certified stock that has been transacted. There is also evidence that some investors are positively screening eco-certified office assets. A number of investors have only acquired eco-certified assets in the study period: others have allocated the vast majority of the expenditure on Class A office to eco-certified offices. Providing support for the presence of a group of eco-investors in commercial real estate markets, the outcome has been that some investors have relatively high market shares for this type of stock.

A niggling doubt of previous research on green building premiums is that there is a positive relationship between the presence of eco-investors, eco-certification and the relative quality of assets within a broad quality band such as Class A offices. Put simply, assets that are eco-certified and/or purchased by eco-investors may be above average quality assets within their class. This problem has been analyzed in some detail by Atkin et al (2013) in the context of the price effect of REIT buyers. The possible outcome is that the price effects of unobserved quality factors are being misattributed as an ecocertification effect. In contrast to previous research, a striking finding of this research is that buyer type is not a significant price determinant. In particular, we find no evidence of a REIT premium. Our results suggest that, perhaps not surprisingly, there is a 'market share premium' in that Class A offices acquired by investors who obtain a high proportion of assets tend to sell for higher prices. This effect is strongest for investors who have a 
high market share of eco-certified Class A office space when they acquire eco-certified space. Turning to the question of the relationship between market share and transaction prices, the empirical results provide evidence of significant positive price effects of market share. This suggests that eco- investors are creating clientele effects that are significant determinants of the price premiums for eco-certified office space and that they may be subject to a green winner's curse. 


\section{References}

Adams, P.D., Kluger, B.D., Wyatt, S.B. (1992). Integrating auction and search markets: the slow Dutch auction. J. Real Estate Financ. Econ. 5 (3): 239-253.

Akin, S., V. Lambson, G. McQueen, B. Plat, B. Slade, and J. Wood. (2013). Rushing to Overpay: Modeling and Measuring the REIT Premium, Journal of Real Estate Finance and Economics, 47: 506 - 537.

Bauer, R. Koedijk, K. and Otten, R. (2005). International evidence on ethical mutual fund performance and investment style, Journal of Banking and Finance, $29,1751-1767$.

Benjamin, J. D., Chinloy, P., Hardin, W. G. and Wu, Z. (2008). Clientele effects and condo conversions. Real Estate Economics 36(3): 611-634.

Bond, S., \& Devine, A. (2016a). Certification matters: is green talk cheap talk? Journal of Real Estate Finance and Economics, 52: 117-140.

Bond, S., \& Devine, A. (2016b). Incentivizing Green Single-Family Construction: Identifying Effective Government Policies and Their Features. Journal of Real Estate Finance and Economics, 52: 383-407.

Brounen, D., \& Kok, N. (2011). On the economics of energy labels in the housing market. Journal of Environmental Economics and Management, 62: 166-179.

Chegut, A., Eichholtz, P. and Kok, N. (2014). Supply, demand and the value of green buildings. Urban Studies 51:22-43.

Choi, E. (2010). Green on Buildings: The Effects of Municipal Policy on Green Building Designations in America's Central Cities, Journal of Sustainable Real Estate 2: 1-21.

Deng, Y. and $\mathrm{Wu}$, J. (2013). Economic returns to residential green building investment: The Developers' perspective. Regional Science and Urban Economics 47: $35-44$.

Devine, A. and Kok, N. (2015). Green Certification and Building Performance: Implications for Tangibles and Intangibles. The Journal of Portfolio Management 41: 61-51. 
Eichholtz, P., Kok, N. and Quigley, J. (2009). Why Do Companies Rent Green? A Model of Ecological Responsiveness, Academy of Management Journal 434: 717737.

Eichholtz, P, Kok, N and Quigley, J. (2010). Doing Well By Doing Good? Green Office Buildings, American Economic Review 100: 2492-2509.

Eichholtz, P., Kok, N., and Quigley, J. (2013). The economics of green building. The Review of Economics and Statistics, 95(1): 50-63.

Fuerst, F. (2009). Building Momentum: An Analysis of Investment Trends in LEED and Energy Star-Certified Properties, Journal of Retail and Leisure Property 8: 2332.

Fuerst F., Kontokosta C., McAllister P. (2014). Determinants of green building adoption. Environment and Planning B: Planning and Design 41:551-570.

Fuerst, F., and McAllister, P. (2009). An Investigation of the effect of eco-labeling on office occupancy rates. Journal of Sustainable Real Estate, 1(1): 49-64.

Fuerst, F., and McAllister, P. (2011a). Eco-labeling in Commercial Real Office Markets: Do LEED and Energy Star Offices Obtain Multiple Premiums? Ecological Economics 70: 1220-30.

Fuerst, F., \& McAllister, P. (2011b). Green noise or green value? Measuring the effects of environmental certification on office values. Real Estate Economics, 39(1): 45-69.

Hardin, W. and Wolverton, M. (1999). Equity REIT Property Acquisitions: Do Apartment REITs Pay a Premium? The Journal of Real Estate Research 17: 113126.

Jackson J. (2010). Promoting energy efficiency investments with risk management decision tools. Energy Policy 38: 3865-3873.

Kahn, M. E. and Kok, N. (2014). The capitalization of green labels in the California housing market. Regional Science and Urban Economics 47: 25-34.

Kats, G. H. (2003). Green building costs and financial benefits. Cambridge, MA: Massachusetts Technology Collaborative. 
Kok N., McGraw M., Quigley J. M. (2011). The diffusion of energy efficiency in building. American Economic Review 101: 77-82.

Kok N., McGraw M., Quigley J. M. (2012). The diffusion over time and space of energy efficiency in building. Annals of Regional Science 48: 541-564.

Kotchen, M. J. (2006). Green markets and private provision of public goods. Journal of Political Economy 114: 816-834.

Lambson, V., McQueen, G. and Slade, B. (2004). Do Out-of-State Buyers Pay More for Real Estate? An Examination of Anchoring-Induced Bias and Search Costs. Real Estate Economics 32: 85-126.

Ling, D. and Petrova, M. (2012). Heterogeneous Investors, Negotiation Strength \& Asset Prices in Private Markets: Evidence from Commercial Real Estate. Aestimum XLI Meetings Proceedings (Rome) 5-40, http://www.fupress.net/index.php/ceset/issue/view/958.

Matisoff, D., D. Noonan, and M. Flowers. (2016). Policy Monitor-Green Buildings: Economics and Policies. Rev Environ Econ Policy 10: 329-346.

Matthews, S. (1995). A Technical Primer on Auction Theory I: Independent Private Values, CMSEMS Discussion Papers, No. 1096, Northwestern University.

Mayer, C.J. (1995). A model of negotiated sales applied to real estate auctions. $J$. Urban Econ. 38 (1): 1-22.

Miller, N, Spivey, J. and Florance, A. (2008). Does Green Pay Off ?, Journal of Real Estate Portfolio Management 14: 385-399.

Nollet, J., Filis, G., and Mitrokostas, E. (2016). Corporate social responsibility and financial performance: A non-linear and disaggregated approach, Economic Modelling, 52(B): 400-407.

Potoski M., Prakash A. (2005). Green clubs and voluntary governance: ISO 14001 and firms' regulatory compliance. American Journal of Political Science 49: 235248.

Quan, D.C. (1994). Real estate auctions: a survey of theory and practice. J. Real Estate Financ. Econ. 9 (1): 23-49. 
Reichardt, A. (2014). Operating expenses and the rent premium of energy star and LEED certified buildings in the central and eastern U.S. Journal of Real Estate Finance and Economics 49: 413-433.

Renneboog, L., Ter Horst, J. and Zhang, C. (2008a). Socially Responsible Investments: institutional aspects, performance and investment behaviour, Journal of Banking and Finance, 32: 1723-1742.

Renneboog, L., Ter Horst, J. and Zhang, C. (2008b). The price of ethics and stakeholder governance: The performance of socially responsible mutual funds, Journal of Corporate Finance, 14: 302-322.

Rosen, S. (1974). Hedonic prices and explicit markets: production differentiation in pure competition. Journal of Political Economy 82: 34-55.

Shen, C., Wu, M., Chen, T., and Fang, T. (2016). To engage or not to engage in corporate social responsibility: Empirical evidence from global banking sector, Economic Modelling, 55: 207-225.

Singh A., Syal M., Grady S. C., Korkmaz S. (2010). Effects of green buildings on employee health and productivity. American Journal of Public Health 100: 16651668.

Turban D. B., Greening D. W. (1997). Corporate social performance and organizational attractiveness to prospective employees. Academy of Management Journal 40: 658-672.

Wiley, J, Benefield, J. and Johnson, K. (2010). Green Design and the Market for Commercial Office Space, Journal of Real Estate Finance and Economics 41: 228-243. 
Appendix 1: Description of variables.

\begin{tabular}{|c|c|}
\hline \multicolumn{2}{|r|}{ Description of variables } \\
\hline $\begin{array}{l}\text { Independent } \\
\text { variables }\end{array}$ & \\
\hline Age & $\begin{array}{l}\text { is a binary variable set to indicate one at a given age of } \\
\text { property. }\end{array}$ \\
\hline Renovated & $\begin{array}{l}\text { is a binary variable set to indicate one at a given number of } \\
\text { years since major refurbishment. }\end{array}$ \\
\hline Sale price & represents the natural logarithm of sale price psf in real terms \\
\hline Occupancy rate & represents the percentage of the building that is leased \\
\hline Size & represents the natural logarithm of the rentable building area \\
\hline Stories & is the natural logarithm of the number of stories \\
\hline Plot size & $\begin{array}{l}\text { represents the natural logarithm of the area of the site on } \\
\text { which building is situated }\end{array}$ \\
\hline Bank & $\begin{array}{l}\text { is a binary variable set to indicate one if the property has a } \\
\text { bank branch or ATM in the building }\end{array}$ \\
\hline Fitness center & $\begin{array}{l}\text { is a binary variable set to indicate one if the property has a } \\
\text { gym }\end{array}$ \\
\hline Airconditioning & $\begin{array}{l}\text { is a binary variable set to indicate one if the property is } \\
\text { completely air-conditioned. }\end{array}$ \\
\hline Onsite manager & $\begin{array}{l}\text { is a binary variable set to indicate one if property manager's } \\
\text { office }\end{array}$ \\
\hline Bus stop & $\begin{array}{l}\text { is a binary variable set to indicate one if the property is } \\
\text { within walking distance of a bus stop. }\end{array}$ \\
\hline Commuter rail & $\begin{array}{l}\text { is a binary variable set to indicate one if the property direct } \\
\text { access to or, if in the suburbs, is within reasonable walking } \\
\text { distance of a commuter rail stop }\end{array}$ \\
\hline $\begin{array}{l}\text { Conference } \\
\text { suite }\end{array}$ & $\begin{array}{l}\text { is a binary variable set to indicate one if the property has } \\
\text { conference facilities }\end{array}$ \\
\hline Convenience & $\begin{array}{l}\text { is a binary variable set to indicate one if the property has a } \\
\text { convenience store }\end{array}$ \\
\hline Atrium & $\begin{array}{l}\text { is a binary variable set to indicate one if the property has a } \\
\text { lobby with a high, vaulted ceiling or a grand, central court } \\
\text { that separates two halves of a large building }\end{array}$ \\
\hline Bank & $\begin{array}{l}\text { is a binary variable set to indicate one if the property has } \\
\text { banking facilities in the building }\end{array}$ \\
\hline Corner lot & $\begin{array}{l}\text { is a binary variable set to indicate one if the property is } \\
\text { situated on corner lot }\end{array}$ \\
\hline Dry cleaner & is a binary variable set to indicate one if the property has dry \\
\hline
\end{tabular}




\begin{tabular}{l|l}
\hline Food services & $\begin{array}{l}\text { cleaning facilities in the building. } \\
\text { is a binary variable set to indicate one if the property has a } \\
\text { cafeteria facility } \\
\text { is a binary variable set to indicate one if the property has } \\
\text { exterior signage. } \\
\text { is a binary variable set to indicate one if the property has on } \\
\text { street parking facilities } \\
\text { is a binary variable set to indicate one if the property has a } \\
\text { lobby attendant provided by the building owner to assist } \\
\text { tenants of the building with special requests. } \\
\text { is a binary variable set to indicate one if the property is } \\
\text { within an } 800 \text { m radius of a rail terminus. } \\
\text { is a binary variable set to indicate one if the property has a } \\
\text { restaurant in the building. } \\
\text { is a binary variable set to indicate one if the property has } \\
\text { constant access. } \\
\text { Is a binary variable set to indicate one of the property is } \\
\text { either LEED or Energy Star certified }\end{array}$ \\
\hline submarket & $\begin{array}{l}\text { is a binary variable indicating in which of the } i \text { submarkets } \\
\text { that the property is located in. Submarkets are divisions of } \\
\text { the primary market that are generally recognizable to the real } \\
\text { estate industry and the business community by the names } \\
\text { given to the areas. For instance, the Manhattan market } \\
\text { consists of 20 submarkets. In total, we use 545 submarkets. }\end{array}$ \\
\hline
\end{tabular}

